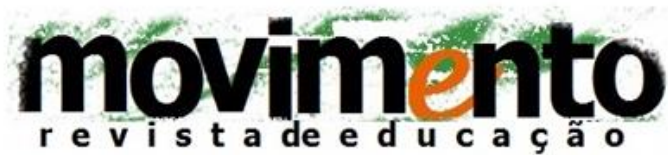 \\ faculdade de educação - programa de pós-graduação em educação \\ universidade federal fluminense \\ issn 2359-3296 \\ ano 4 número 7 - 2017
}

\section{O SENTIDO DA FORMAÇÃO HUMANA E AS POSSIBILIDADES PEDAGÓGICAS DO ALFABETIZADOR COM CRIANÇAS NA EDUCAÇÃO FUNDAMENTAL A PARTIR DO DIÁLOGO COM PAULO FREIRE}

\author{
Odiliana Ribeiro de Souza ${ }^{1}$
}

\begin{abstract}
Resumo
O artigo, baseado no pensamento de Paulo Freire, compreende o sentido da formação humana como possibilidade ontológica do homem em ser sujeito e não objeto de outros homens. Critica a visão "bancária" da educação e dialoga com a perspectiva libertadora ao se apresentar como uma possibilidade de conscientização política desde os processos iniciais de alfabetização. Aponta a necessidade de proposições educativas elaboradas a partir de um pensar coletivo com os educandos e não para eles. Nesse diálogo com Freire, sugere alguns elementos necessários na alfabetização de crianças. Palavras-chave: Alfabetização de crianças; Educação popular; Trabalho docente.
\end{abstract}

\section{THE SENSE OF HUMAN TRAINIG AND THE PEDAGOGICAL POSSIBILITIES OF THE LITERACY WITH CHILDREN IN FUNDAMENTAL EDUCATION FROM THE DIALOGUE WITH PAULO FREIRE}

\begin{abstract}
The article, based on the thought of Paulo Freire, understands the meaning of human formation as an ontological possibility of man to be subject and not the object of other men. It criticizes the "banking" vision of education and dialogues with the liberating perspective when presenting itself as a possibility of political awareness from the initial processes of literacy. It points out the need for educational propositions elaborated from a collective thinking, with the learners and not for them. In this dialogue with Freire, he suggests some necessary elements in children's literacy.

Keywords: Literacy of children; Popular education; Teaching work.
\end{abstract}

\footnotetext{
1 Mestranda em Educação Brasileira pela Universidade Federal de Goiás (UFG). Linha de Pesquisa: Educação, Trabalho e Movimentos Sociais. Graduada em Direito e Pedagogia pela UFG. odiliana@hotmail.com.
} 


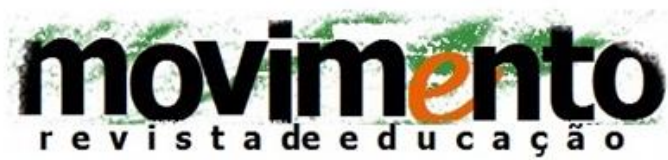 \\ faculdade de educação - programa de pós-graduação em educaçăo \\ universidade federal fluminense \\ issn 2359-3296 \\ ano 4 número 7 - 2017
}

\section{EI SENTIDO DE LA FORMACIÓN HUMANA Y LAS POSIBILIDADES PEDAGÓGICAS DEL ALFABETIZADOR CON NIÑOS EM LA EDUCACIÓN FUNDAMENTAL A PARTIR DEL DIÁLOGO CON PAULO FREIRE}

\begin{abstract}
Resumen
El artículo, a partir del pensamiento de Paulo Freire, comprende el sentido de la formación humana como posibilidad ontológica del hombre en ser sujeto y no objeto de otros hombres. Critica la visión "bancaria" de educación y dialoga con la perspectiva liberadora al presentarse como una posibilidad de concientización política desde los procesos iniciales de alfabetización. Señala la necesidad de proposiciones educativas elaboradas a partir de un pensamiento colectivo, con los educandos y no para ellos. En este diálogo con Freire, sugiere algunos elementos necesarios en la alfabetización de niños.

Palabras clave: Alfabetización de niños; Educación Popular; Trabajo Docente.
\end{abstract}

\section{Introdução}

Aos esfarrapados do mundo e aos que neles se descobrem e, assim descobrindo-se, com eles sofrem, mas, sobretudo, com eles lutam.

Paulo Freire (1987, p.23)

Se penso a leitura e a escrita como experiência, é porque as entendo como 'locus' da indignação e da resistência. Sonia Kramer (2003, p. 67)

Abordar os sentidos da formação humana a partir da perspectiva libertadora de Paulo Freire se constitui em uma opção política, digamos, ousada no atual contexto educacional e político de nosso país. Isso porque vai na contramão das propostas que contam com forte apelo social e que se valem da consciência ingênua da população para, em uma disputa ideológica, arrebanharem fiéis sob o véu da ignorância, como fazem os movimentos que apregoam a camuflada defesa partidária de uma escola sem partido.

É ousada também por ir contra perspectivas que adentram as escolas, reavivadas pelas políticas educacionais brasileiras e baseadas na repaginação de velhos métodos de alfabetização, mantendo, assim, a mesma base 


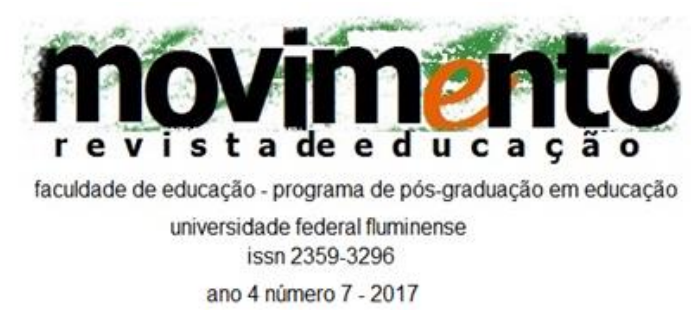

epistemológica pautada na cópia, na memorização e na repetição quanto aos processos de aprendizagem da leitura e da escrita. Tais bases epistemológicas, denunciam a visão de uma linguagem, ora como mera expressão do pensamento, ora como um instrumento de comunicação. Ambas, compreendem um sujeito perceptivo e passivo, com foco na abstração do código escrito, e propõem práticas pedagógicas que desconsideram os sentidos e os significados da linguagem para os sujeitos nas práticas de escrita.

Como contraposição a essas perspectivas da linguagem, Paulo Freire nos lança o convite de pensá-la como forma de interação dialógica, visando a uma transformação dos sujeitos, no sentido de conscientização, com a intenção de alcançar a mudança social. Dessa forma, tal autor nos propõe pensar a alfabetização para além dos limites do que está posto e nos instiga a problematizar a alfabetização, a aprendizagem, o ensino e as experiências do trabalho docente.

Nesse contexto, Paulo Freire nos provoca como educadores a interferirmos no mundo através do comprometimento e da coerência de uma prática educativa dialógica e consciente para, dessa forma, realizarmo-nos enquanto humanos. A dimensão formativa é mais uma vez levantada quando destacamos o nosso papel social como educadores responsáveis pelo processo formativo de personalidades democráticas.

O autor denuncia a não neutralidade e a a-historicidade do sentido da educação. Reafirma que o processo educativo é sempre situado e datado no tempo e no espaço, fato que apreende as dimensões políticas, econômicas, sociais e epistemológicas. Dessa forma, pensar os sentidos da alfabetização, bem como de suas práticas pedagógicas, implica reconhecer criticamente a sua função social nos diferentes momentos históricos. 


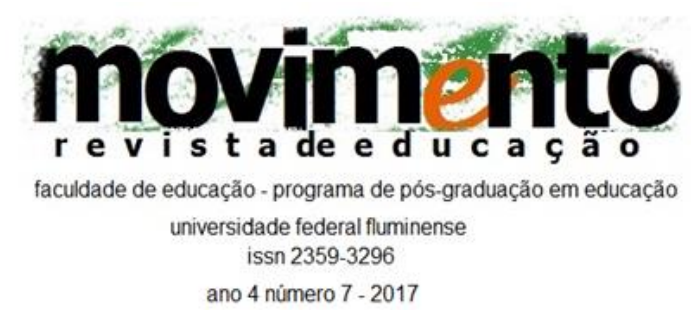

O sentido da formação para Freire (1997), ao apontar a vocação ontológica de humanização, de um ser mais enquanto potencialidade, pontua claramente a escola que queremos como espaço público e popular, de direito de todos. Esse direito deve ser materializado por meio de práticas pedagógicas que enfoquem a apreensão crítica do conhecimento científico por meio de relações dialógicas. A luta é por uma escola que estimula o aluno a pensar, a perguntar, a criar e a criticar. Que se proponha a construir um conhecimento coletivo, articulando os saberes populares ao saber científico, de forma crítica, mediados pelas experiências no mundo.

Ao tratarmos de alfabetização para crianças, o diálogo com Paulo Freire amplia - nosso olhar ao trazer a sua perspectiva dialógica e política para reconhecermos a criança como um sujeito do conhecimento. Já a leitura da palavramundo potencializa nossos modos de ver, de entender e de conceber esse mundo e, enquanto processo, vamos nos dando conta de que a realidade é também uma produção humana e, portanto, não é natural e a-histórica, sendo possível de ser transformada.

\section{O sentido da formação humana na perspectiva libertadora de Paulo Freire}

A perspectiva libertadora de educação, apregoada nos estudos de Paulo Freire, surge na segunda metade da década de 1950, em um contexto social de mudanças em relação à discussão sobre o analfabetismo de adultos no Brasil. Naquele contexto, várias críticas eram feitas à visão de que o analfabeto estaria desligado dos problemas sociais. E, Paulo Freire desde aquele momento, já apontava que o desenvolvimento exigia a participação consciente do povo em uma perspectiva democrática. 


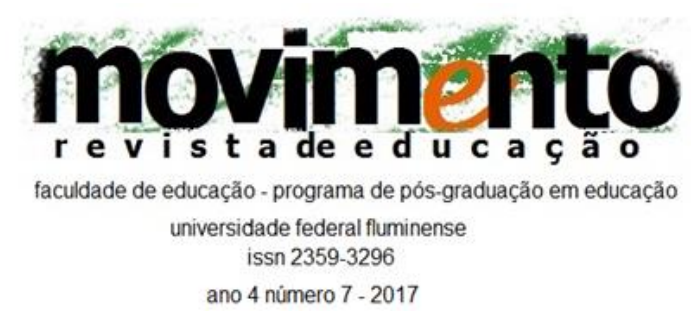

Tal entendimento considerava necessário formar a consciência crítica a partir da singularidade do contexto social do educando e do esclarecimento sobre a situação de opressão e da tensa relação entre oprimidos e opressores. Vislumbra-se, assim, o desenvolvimento da consciência crítica desde o processo inicial de alfabetização, pautada na historicidade, na compreensão dos fatos e na percepção dos fatores que os determinam, tendo, como ideal, uma formação humana voltada para a autonomia e para o autogoverno. (BEISIEGEL,2008).

O ideal da educação libertadora de Paulo Freire não está restrito à educação de adultos. Ele extrapola essa mera classificação ao se propor romper com as práticas pedagógicas que, em sua essência, constituem-se assistencialistas, domesticadoras e deformadoras dos sujeitos, mediante metodologias que incorporam a passividade dos educandos através do antidiálogo. Tais práticas, nesse entendimento, tornam-se uma violência contra os sujeitos, negando o caráter ético e político dos fins da educação. Como oposição a essas ideias, Paulo Freire traz as contribuições de Marx e Gramsci para compreender as origens da dominação classista e as possibilidades de rompimento com essa realidade. Para isso, ele elenca a conscientização como meio de promover a articulação teórico-prática visando à superioridade humana e à humanização.

Como denúncia, Freire critica a escola que desvincula o seu currículo da realidade dos educandos. Essa que está cada vez mais pobre e esvaziada de sentido e de significados sobre o seu propósito. Como contraposição a essa realidade, o autor anuncia a lógica de uma educação para a classe popular através de práticas contextualizadas e pautadas na relação dialógica, constituindo, assim, uma possibilidade de formação tanto para os educadores quanto para os educandos.

Freire (1987) compreende que a Educação é uma forma de intervenção na realidade com a finalidade de restaurar a humanidade roubada dos oprimidos e 


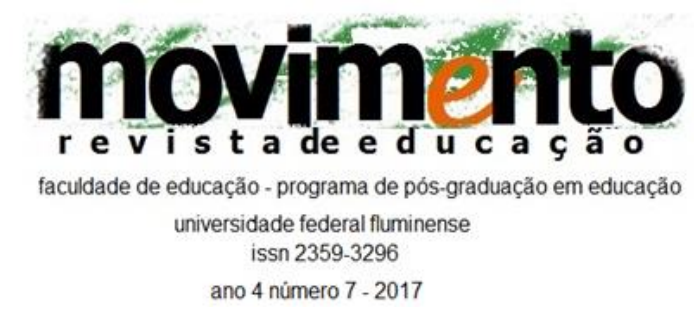

dos opressores. Sobre essa necessária superação da opressão, Paulo Freire denuncia:

\begin{abstract}
A violência dos opressores que os faz também desumanizados, não instaura uma outra vocação - a do ser menos. Como distorção do ser mais, o ser menos leva os oprimidos, cedo ou tarde, a lutar contra quem os fez menos. E esta luta somente tem sentido quando os oprimidos, ao buscar recuperar sua humanidade, que é uma forma de criá-la, não se sentem idealistamente opressores, nem se tornam, de fato, opressores dos opressores, mas restauradores da humanidade em ambos. E aí está a grande tarefa humanista e histórica dos oprimidos - libertarse a si e aos opressores. Estes, que oprimem, exploram e violentam, em razão do seu poder, não podem ter, neste poder, a força de libertação dos oprimidos nem de si mesmos. Só o poder que nasça da debilidade dos oprimidos será suficientemente forte para libertar a ambos. (FREIRE, 1987, p.16).
\end{abstract}

Assim, o ato de oprimir um outro ser humano só denuncia a desumanização presente também na figura do opressor, pois reconhecer o caráter humano e a humanidade em todas as pessoas é uma das características inevitáveis da humanização. E, nesse sentido, Freire aponta, ao longo de suas obras, alguns princípios fundamentais para reafirmar esse propósito: o diálogo como forma de humanização, a educação com a finalidade de conscientização e liberdade através de práticas pedagógicas que exercitem a comunhão entre os seres humanos. Pois, o oprimido não se liberta sozinho, sendo necessário o engajamento entre os homens.

O diálogo, para Paulo Freire, não é uma técnica para se conseguir bons resultados ou uma tática para fazer amizade com os alunos. O diálogo é o "momento em que os humanos se encontram para refletir sobre sua realidade tal como a fazem e re-fazem" (SHOR e FREIRE, 1986, p.123). Essa ocasião reflexiva tem uma dimensão individual e social ao mesmo tempo, pois é realizada entre sujeitos que se constituem como seres sociais. Nesse sentido, o diálogo é uma relação democrática entre os sujeitos. Por isso, se ambos não estiverem em condição de igualdade, se não houver trocas, cria-se, na verdade, um monólogo, denunciando aí a sua característica de dominação. 


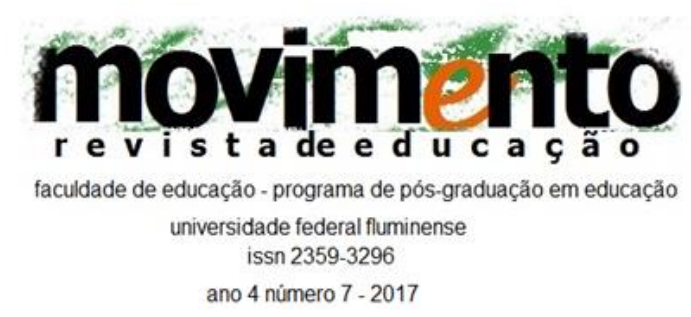

Dessa forma, o diálogo se confirma como fundamento antropológico para a construção de um projeto de humanização e de emancipação humana, tanto do oprimido quanto do opressor, bem como uma possibilidade coletiva, histórica e socialmente construída. O movimento da dialogicidade propõe o esclarecimento, a problematização da realidade e a ampliação da criticidade sobre o real aos sujeitos, por meio do desenvolvimento do nível de consciência, potencializando a materialização da mudança social:

Enquanto seres humanos conscientes, podemos descobrir como somos condicionados pela ideologia dominante. Podemos distanciar-nos da nossa época. Podemos aprender, portanto, como nos libertar através da luta política na sociedade. Podemos lutar para ser livres, precisamente porque sabemos que não somos livres! É por isso que podemos pensar na transformação. (SHOR e FREIRE, 1986, p. 25).

Esse encontro dos sujeitos na linguagem enquanto interação, em uma perspectiva discursiva, é cheio de sentidos e de significados para eles, pois pode ampliar o conhecimento científico, levando-os à criticidade em uma constante reconstrução de si e do social, já que "aprender e mudar a sociedade caminham juntos" (SHOR e FREIRE, 1986, p.66). Dessa forma, o sentido da vida é ressignificado perante a libertação da lógica de uma cultura que nos desumaniza e nos impossibilita de sermos mais, mais humanos. Essa é a esperança, a utopia de Freire:

Enquanto projeto, enquanto desenho de um mundo diferente, menos feio, o sonho é tão necessário aos sujeitos políticos, transformadores do mundo e não adaptáveis a ele, quanto é para o trabalhador, que projete em seu cérebro o que vai executar antes mesmo da execução. (FREIRE,1997, p. 99).

Nesse sonho de transformar a cultura e construir um mundo socioculturalmente estruturado, Freire convoca, com ousadia, os sujeitos para juntos construírem esse novo lugar: 


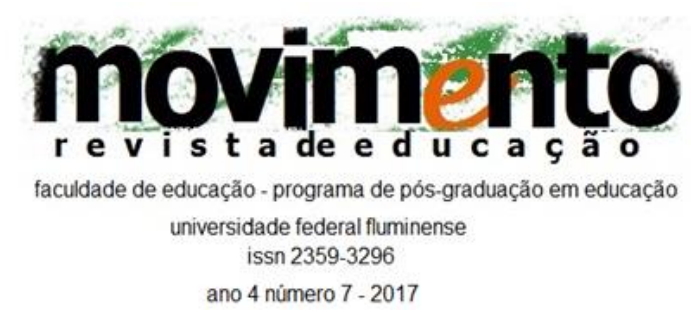

Homens e mulheres, ao longo da história, vimo-nos tornando animais deveras especiais: inventamos a possibilidade de nos libertar na medida que nos tornamos capazes de nos perceber como inconclusos, limitados, condicionados, históricos. Percebendo, sobretudo, também, que a pura percepção da inconclusão (...) não basta. É preciso juntar a ela a luta política pela transformação do mundo. (FREIRE, 1997, p.100).

Como forma de problematizar a educação como prática da liberdade, Freire (1987) desafia homens e mulheres a descobrirem que pouco sabem de si e a se inquietarem frente a essa condição para saberem mais. E que, além disso, a descoberta crítica da desumanização deve estar atrelada a grande tarefa humanista e histórica do oprimido em libertar a si e aos opressores. Daí a impossibilidade de construir uma pedagogia para os oprimidos, pois criar algo para o outro, colocando-o como alguém à parte do evento, só geraria uma opressão camuflada, mais depósitos em um processo educativo sem sentido. Assim, é necessário cultivar a solidariedade com quem se encontra no estado de coisa, sendo esse compromisso uma necessidade para os educadores. Sobre o exposto, o autor complementa:

Por isto é que o poder dos opressores, quando se pretende amenizar ante a debilidade dos oprimidos, não apenas quase sempre se expressa em falsa generosidade, como jamais a ultrapassa. Os opressores, falsamente generosos, tem necessidade, para que a sua "generosidade" continue tendo oportunidade de realizar-se, da permanência da injustiça. A "ordem" social injusta é a fonte geradora, permanentemente, desta "generosidade" que se nutre da morte, do desalento e da miséria. (FREIRE, 1987, p. 16).

Nesse sentido, o autor esclarece os perigos da "generosidade nutrida pelo falso amor e pontua que a libertação da condição de opressão não se dará pelo acaso, mas pela práxis da busca" (FREIRE, 1987, p.16). Assim, a generosidade verdadeira dos esclarecidos, nutrida pela luta e pelo reconhecimento da humanidade do oprimido, torna-se possibilidade, instrumento para a descoberta crítica dos oprimidos por si mesmos, sem a participação do opressor. 


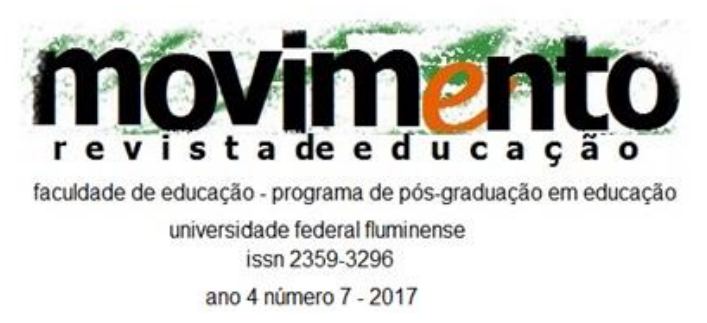

Já na obra Pedagogia da Esperança (1997), Freire reafirma a esperança como uma necessidade ontológica para nos posicionarmos no movimento de luta e de superação da opressão. Na obra, o autor amplia seu olhar para denunciar as diferentes nuances da opressão, que inicialmente estavam restritas à questão de classe e ao trabalhador explorado, e que agora contemplam também as diversas identidades dos sujeitos oprimidos, marginalizados, explorados e excluídos: o camponês, o negro, o índio, o mestiço, a mulher, o portador de deficiência, etc.

Em Conscientização: Teoria e prática da libertação (1979), Paulo Freire destaca a importância do compromisso histórico desses oprimidos para que assumam a posição de fazer e refazer o mundo, ou seja, a responsabilidade com transformação social.

Para mim o utópico não é o irrealizável; a utopia não é o idealismo, é a dialetização dos atos de denunciar e anunciar, o ato de denunciar a estrutura desumanizante e de anunciar a estrutura humanizante. Por esta razão a utopia é também um compromisso histórico. A utopia exige o conhecimento crítico. É um ato de conhecimento. Eu não posso denunciar a estrutura desumanizante se não a penetro para conhece-la. Não posso anunciar se não conheço, mas entre o momento do anúncio e a realização do mesmo existe algo que deve ser destacado: é que o anúncio não é anúncio de um ante-projeto, porque é na práxis histórica que o anteprojeto se torna projeto. É atuando que posso transformar meu anteprojeto em projeto; na minha biblioteca tenho um anteprojeto que se faz projeto por meio da práxis e não por meio do blábláblá. (FREIRE, 1980, p.16).

Esse resgate da utopia como possibilidade de mudança se materializa através de formas coletivas de intervenção, sempre tendo em vista que se conscientizar é tomar consciência durante o processo, é denunciar a relação de opressão e anunciar ao mesmo tempo a possibilidade de mudança.

É através desse engajamento político-pedagógico que Freire compreende a vocação ontológica do homem em ser sujeito e não objeto dos outros. Para isso, seu projeto educativo contempla o ato de pensar com e não para os sujeitos 


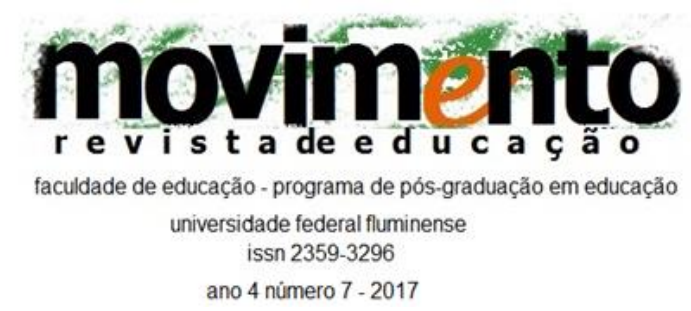

envolvidos nesse processo. Além disso, ela destaca que a educação deve considerar as condições em que o sujeito vive "em tal lugar exato, em tal momento, em tal contexto" (FREIRE, 1980, p. 19), e uma educação que não considere os educandos se constitui como bancária, por apenas depositar conhecimentos. Sobre a concepção bancária, Freire (1980) a caracteriza:

O professor fala da realidade como se esta fosse sem movimento, estática, separada em compartimentos e previsível; ou então, fala de um tema estranho à experiência existencial dos estudantes: neste caso sua tarefa é "encher" os alunos do conteúdo da narração, conteúdo alheio à realidade, separado da totalidade que a gerou e poderia dar-Ihe sentido. Assim, a educação passa a ser "o ato de depositar", no qual os alunos são os depósitos e o professor aquele que deposita. Em lugar de comunicar, o professor dá comunicados que os alunos recebem pacientemente, aprendem e repetem. É a concepção "acumulativa" da educação (concepção bancária). (FREIRE, 1980, p. 41).

Considerar o sujeito no processo educativo é o pressuposto básico da educação problematizadora e revolucionária proposta por Freire (1980), ao se contrapor à educação bancária, buscando uma reflexão verdadeira sobre a realidade a partir da historicidade humana. Nesse processo, o diálogo é possível e necessário porque o outro é reconhecido enquanto sujeito e é nesse encontro através da linguagem que homens se descobrem incompletos e inacabados como humanos.

Nesse sentido, a formação, na perspectiva libertadora de Paulo Freire, é necessária e também um compromisso político, porque recupera e potencializa a humanização dos sujeitos envolvidos no processo educativo. A práxis pedagógica se torna o espaço/tempo dialógico em que educadores e educandos captam os fatos da vida real do cotidiano dos educandos para, através do ato comprometido de problematizar essa realidade, denunciar a opressão dos oprimidos e anunciar a utopia coletiva de superação dessa relação de exploração social. 


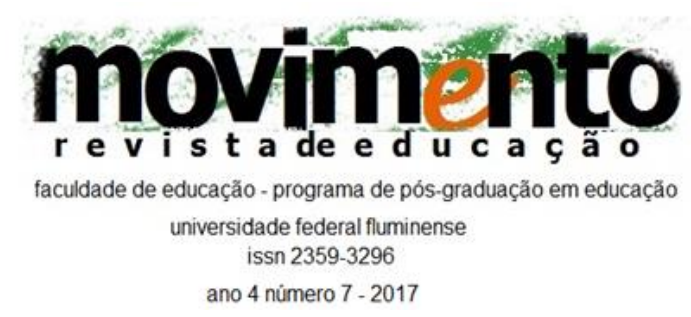

Assim, essa proposta de educação se torna ousada por apontar uma humanização que só se realiza plenamente enquanto o homem se configura como ser que interfere no mundo, enquanto sujeito e classe, até atingir a coletividade nacional. E essa interferência só é possível mediante uma formação que consiga provocar a consciência crítica do sujeito.

\section{A alfabetização para Paulo Freire}

Freire (1989), ao tratar da alfabetização, apresenta uma proposta formativa que reafirma o princípio da dignidade humana como possibilidade universal e como algo materialmente possível de ser realizável. Dignidade por apresentar uma forma de trabalho que respeita, valoriza e parte dos conhecimentos do educando para ampliar os saberes científicos, que devem ser o efetivo objeto de trabalho da escola. Também se constitui como proposição plenamente materializável por trazer conceitos filosóficos de maneira clara (de fácil entendimento para os docentes) e de maneira simples (porém não simplista). Daí o marco enquanto teórico da educação. Para Freire, o ponto de partida da relação pedagógica entre educadores e educandos é a coerência de um processo instituído no falar com e não no falar para. Essa postura de respeito reflete um movimento democrático e libertador, que não liberta de cima para baixo, mas busca romper com as estruturas autoritárias que estão incrustadas na educação, consciente e/ou inconscientemente.

O compromisso político de recuperar a humanidade do oprimido se materializa em uma proposta que não dicotomiza a relação entre leitura do mundo e da palavra, desde o contato inicial do educando com as práticas alfabetizadoras. Dessa forma, a leitura da palavramundo é um processo de reflexão sobre os determinantes em que o sujeito está imerso e as possibilidades de ação nessa realidade a partir da tomada de consciência. Nesse sentido: 


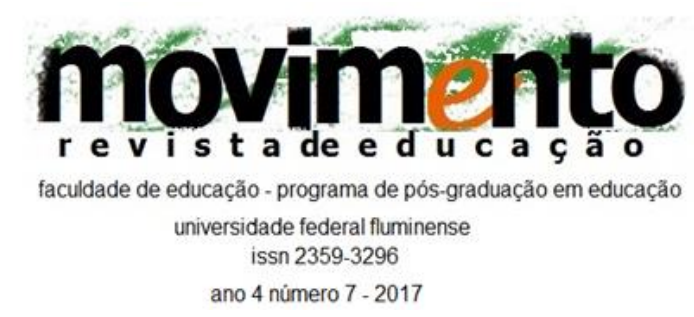

[...] aprender a ler o mundo, compreender o seu contexto, não numa manipulação mecânica de palavras, mas numa relação dinâmica que vincula linguagem e realidade. Ademais, a aprendizagem da leitura e a alfabetização são atos de educação e educação é um ato fundamentalmente político. (FREIRE, 1989, p.7).

A educação como ato político evoca a necessidade de um posicionamento crítico, por parte dos educadores, no sentido de ter práticas pedagógicas cada vez mais coerentes com a proposição política que defende. Nesse movimento humanizador, educandos e educadores se formam enquanto humanos, ambos são sujeitos nesse processo e tomam para si um projeto comum e solidário de libertação das relações sociais de opressão. Esse processo se apresenta como formativo ao educador, pois

[...] quem forma se forma e re-forma ao formar [...] é neste sentido que ensinar não é transferir conhecimentos, conteúdos nem formar é ação pela qual um sujeito criador dá forma, estilo ou alma a um corpo indeciso e inanimado. (FREIRE, 1989, p.12).

Se essa coerência ética entre o que se fala e o que se faz é necessária, quanto à coerência teórico-metodológica do processo de alfabetização, Paulo Freire criticava o uso de cartilhas e materiais apostiláveis, pois os mesmos se constituem em componentes da educação domesticadora e homogeneizadora, algo que engessa a prática docente, por não considerar a pluralidade dos educandos enquanto sujeitos que vivem em diferentes contextos históricos e sociais. Além disso, o enfoque na construção de palavras e frases sem sentido, acaba por matar as possibilidades de uma escrita rica e cheia de significado para o educando.

Nesse viés, o uso de materiais prontos, como cartilhas e apostilas, em nada contribui para a metodologia dialógica que todo educador deve desenvolver. No entanto, se Paulo Freire descarta a necessidade de um processo homogêneo e fragmentado, que pode ser orientado por qualquer pessoa, o que ele coloca no 


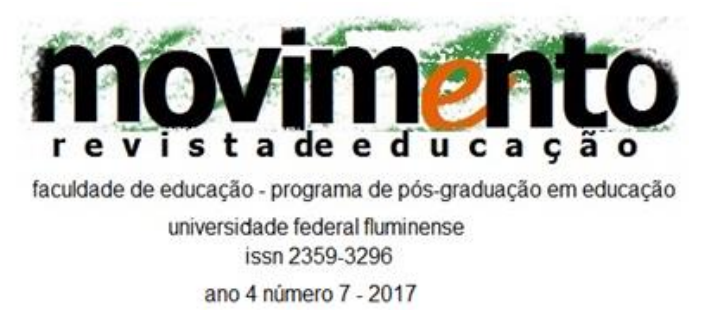

lugar? O eixo norteador de sua proposta de alfabetização se constitui no trabalho com os temas geradores e, para a materialização dessa proposta, ele necessita de um professor, um profissional com formação ética, teórica e prática, que consiga enfrentar os desafios impostos por uma realidade heterogênea quanto aos ritmos de desenvolvimento e aprendizagem dos educandos. Sobre o método Paulo Freire, Gadotti (1996) esclarece:

A eficácia e validade do "Método" consistem em partir da realidade do alfabetizando, do que ele já conhece, do valor pragmático das coisas e fatos da sua vida cotidiana, de suas situações existenciais. O "Método" obedece às normas metodológicas e linguísticas, mas vai além delas, porque desafia o homem e a mulher que se alfabetizam a se apropriarem do código escrito e a se politizarem, tendo uma visão de totalidade da linguagem e do mundo. O "Método" nega a mera repetição alienada e alienante de frases, palavras e sílabas, ao propor aos alfabetizandos "ler o mundo" e "ler a palavra", leituras, aliás, como enfatiza Freire, indissociáveis. Daí ter vindo se posicionando contra as cartilhas. Em suma, o trabalho de Paulo Freire é mais do que um método que alfabetiza, é uma ampla e profunda compreensão da educação que tem como cerne de suas preocupações a sua natureza política. (GADOTTI,1996, p. 39).

Assim, a proposta de alfabetização de Freire não está vinculada ao ensino da repetição de palavras, ou seja, ao aprendizado mecânico de uma técnica, mas ao desafio cognitivo de ler e escrever para desenvolver a capacidade de pensar a realidade, de compreender os conceitos, as palavras e as contradições, e de problematizá-las para interferir no mundo. Para o autor, "a alfabetização não é um jogo de palavras, é a consciência reflexiva de cultura, a reconstrução crítica do mundo humano, a abertura de novos caminhos" (FREIRE, 1987, p.20). Nesse sentido, o método prioriza e articula a alfabetização à cultura popular através da conscientização e politização.

Se o caráter político da alfabetização é destacado, os Círculos de Cultura são movimentos formativos criados para, através de uma organização circular, facilitar e provocar o diálogo. Os temas tratados, nomeados de geradores, 


\section{movimento \\ faculdade de educação - programa de pós-graduaçăo em educação universidade federal fluminense \\ issn 2359-3296 \\ ano 4 número 7 - 2017}

propõem-se a elencar discussões que denunciem os impedimentos à humanização.

Os temas geradores são aqueles que partem da realidade dos educandos, ou seja, palavras carregadas de significação para o grupo e não para o educador. São problemáticas e com natureza social e histórica e não meramente individual. São fruto de um diagnóstico inicial que o educador realiza sobre as singularidades da comunidade. Esse levantamento faz parte da construção da rede temática e baseia-se nas falas sobre os problemas da comunidade. Além disso, é posteriormente validado por esse próprio grupo, antes do início do trabalho com a alfabetização. Esses saberes nascem da inquietação sobre problemas reais e vão tomando corpo científico ao serem problematizados e ao se tornarem matéria prima para aprofundar os conceitos científicos de maneira interdisciplinar, ou seja, ao se constituírem em núcleos tratáveis pelas diferentes áreas do conhecimento.

Após a escolha dos temas geradores, o trabalho da alfabetização se direciona para a exploração das palavras geradoras. Em relação à análise sobre a escrita, as palavras eram escolhidas por terem riqueza fonêmica (critério sintático) e por se constituírem em palavras-chave, com forte entrosamento com a realidade cultural, possibilitando 0 desenvolvimento de temas relacionados à conscientização popular (critério semântico e pragmático). Posteriormente, ocorria o desdobramento das palavras geradoras em sílabas e letras, possibilitando a formação de novas palavras. Em relação à leitura, ou seja, às fichas de leitura, o material apresentava pequenos textos articulados às palavras geradoras e se propunham a realizar uma discussão crítica.

Dessa forma, Paulo Freire reafirma em sua metodologia aquilo que destaca enquanto proposição política, ou seja, todo o processo é elaborado com o educando e não para ele. Sobre isso: 


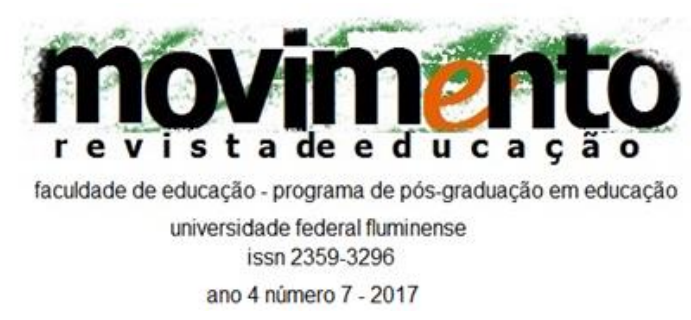

Daí que sempre tenha insistido em que as palavras com que organizar o programa de alfabetização deveriam vir do universo vocabular dos grupos populares, expressando a sua real linguagem, os seus anseios, as suas inquietações, as suas reivindicações, os seus sonhos. Deveriam vir carregadas da significação de sua experiência existencial e não da experiência do educador. A pesquisa do que chamava universo vocabular nos dava assim as palavras do Povo, grávidas de mundo. Elas nos vinham através da leitura do mundo que os grupos populares faziam. Depois, voltavam a eles, inseridas no que chamava e chamo de codificações, que são representações da realidade. (FREIRE, 1989, p. 13).

Nesse sentido, os materiais propostos no método se configuram como desafiadores por trabalhar os aspectos discursivos e políticos, bem como os aspectos notacionais da língua, concomitantemente, a saber, "o texto em um contexto" como afirma Freire (1989, p. 09). O processo de alfabetização ocorria durante debates em que os educandos refletiam sobre os dados de suas próprias vivências e, de uma maneira respeitosa, o diálogo permitia que os mesmos ampliassem suas percepções de mundo e se conscientizassem ao refletirem sobre os determinantes da sua própria condição histórica enquanto oprimido.

Quanto a uma possível aproximação com os termos relativos ao espaço escolar, por se tratar de uma prática pedagógica, mesmo não se restringindo ao espaço da escola, alguns conceitos foram alterados pelo esvaziamento do sentido elaborado até então pelas práticas de educação "bancária". Nessa perspectiva, a divisão ocorria da seguinte maneira: os participantes do grupo de discussão seriam os alunos, os círculos de cultura eram a referência para a classe, os coordenadores do debate se aproximam à figura dos professores e a aula se materializava no debate e diálogo entre educadores e educandos, enquanto o programa se referia às situações existenciais.

A lógica desse trabalho pedagógico se constituía em formadora ao proporcionar a mudança de uma consciência "ingênua" e simplista, que não abarca a historicidade e a compreensão dos fatos, que é idealizadora do passado e frágil 


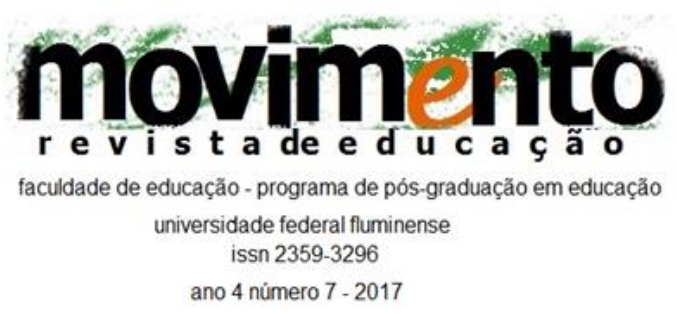

quanto à argumentação, mas rica em conteúdo autoritário, possibilitando a formação de mentalidades passivas. Desse primeiro nível de consciência, passava-se ao nível crítico, mediante estímulos concretos que esclareciam os fatores determinantes das condições de opressão, criticidade rica em conteúdo democrático que afirmava a vocação ontológica humana em "ser mais". (FREIRE, 1989, p. 80).

$\mathrm{Na}$ educação de adultos, toda a problemática social era abordada com os educandos de maneira respeitosa, sempre valorizando o respeito à dignidade do outro. Nessa proposta, era necessário aprender a ler para se apropriar do mundo. A necessidade da organização de um material que não fosse homogêneo de norte ao sul do país e não apresentasse conteúdo infantilizado era uma preocupação de Paulo Freire.

Esses pontos repercutem na forma em que se alfabetiza e no "produto" desse processo, ou seja, no nível de consciência do sujeito alfabetizado e nas suas possibilidades de se colocar através da linguagem na realidade social em que vive. Demonstram uma proposta alfabetizadora que considera o adulto analfabeto como alguém a ser valorizado como humano. Um sujeito que tem saberes, mesmo que não sejam aqueles valorizados pela escola. Possui também uma história de vida e não são uma folha em branco quanto a saberes e experiências, mas estão oprimidos por questões de ordem social. Aprender a ler e a escrever nessa proposta popular passa a ter sentido para os sujeitos alfabetizados, pois o ato de aprender está vinculado à vida real.

Além disso, a conscientização se torna elemento importantíssimo para a compreensão de que não somos sujeitos determinados historicamente, mas, sim, condicionados. Nessa perspectiva, é possível e necessário ocorrerem mudanças e transformações. Aquelas só ocorrem mediante o engajamento político de sujeitos politizados e esclarecidos de suas reais condições de vida. 


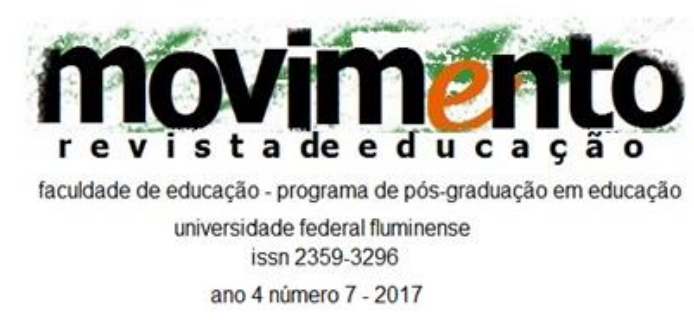

Essa é a finalidade ampla da proposta freireana: ao interferir no mundo, o homem realiza plenamente a sua humanidade.

\section{As possibilidades pedagógicas com crianças na educação fundamental e - trabalho docente do alfabetizador em diálogo com a perspectiva libertadora}

Se Paulo Freire, em alguns momentos, remete-nos à alfabetização popular no contexto de adultos, como, então, organizar uma proposta alfabetizadora para crianças, abarcando os mesmos elementos constitutivos da práxis libertadora? Os elementos primordiais para ela é que seja constituída a partir de um movimento dialógico, pois, independente da faixa etária a que se destina, é necessário partir da escuta e da apreensão da realidade de todos os sujeitos envolvidos no processo educativo para, então, organizar proposições que considerem as especificidades da fase da vida e do contexto social dos educandos.

Baseada no respeito aos sujeitos do processo educativo, em uma perspectiva libertadora, a prática docente exige a ampliação dos saberes no viés crítico pelos educandos, independente da faixa etária deles. Tal propositura pedagógica deve estar pautada na coerência entre o saber-fazer e o saber-ser-pedagógico. A ampliação desses saberes requer do professor a formação de uma identidade docente que se constitui na dimensão ética, política e pedagógica.

Paulo Freire destaca que essa identidade também se caracteriza no rigor do preparo científico do professor, pois "ensinar não é transferir conhecimento, mas criar as possibilidades para a sua produção ou a sua construção" (FREIRE, 1996, p.12). 


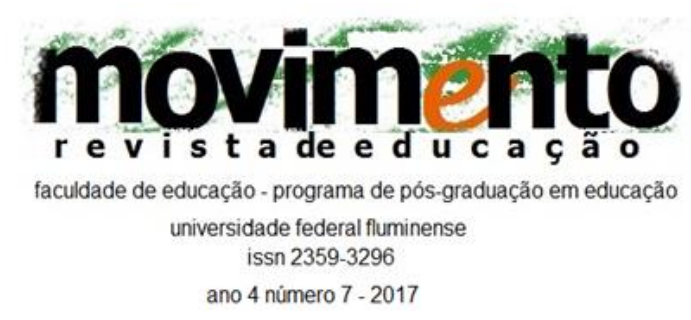

Ao tratar dos elementos que devem estar presentes nos saberes do professor, Freire aponta que ensinar não é algo simples e que se dê de forma espontânea, mas é fruto de constante compromisso, de pesquisa e de dedicação ao ofício docente. Pois, para ele, "não há docência sem discência" (1996, p.11) e o ato de ensinar, além da rigorosidade metódica, mostra-nos a "boniteza" (idem) de nos responsabilizarmos por educar:

Quando vivemos a autenticidade exigida pela prática de ensinar-aprender participamos de uma experiência total, diretiva, política, ideológica, gnosiológica, pedagógica, estética e ética, em que a boniteza deve achar-se de mãos dadas com a decência e com a serenidade. (FREIRE, 1996, p.13).

O respeito aos saberes dos educandos e o autoexame sobre a prática pedagógica são elementos essenciais ao docente que tem consciência do seu próprio inacabamento enquanto ser humano e que compreende que a educação é uma forma de intervenção no mundo.

Quanto à especificidade do trabalho pedagógico com crianças, é importante que o tema gerador esteja permeado de sentido para o educando, que o mobilize a querer saber mais do mundo e de si e que as práticas de escrita sejam formas de interação entre os diferentes sujeitos do espaço escolar, pois é preciso desenvolver na escola uma escrita necessária. Smolka esclarece que "a alfabetização implica, desde a sua gênese, a constituição do sentido. Desse modo, implica, mais profundamente, uma forma de interação com o outro pelo trabalho de escritura - para quem escrevo o que escrevo e por quê?" (SMOLKA, 2008, p. 69).

A partir da ênfase na natureza social do conhecimento e desenvolvimento humano, compreende-se que os modos de agir, de pensar, de falar e de sentir das crianças são constituídos socialmente. O professor tem papel fundamental no processo de aquisição da linguagem escrita. A escrita, enquanto linguagem, 


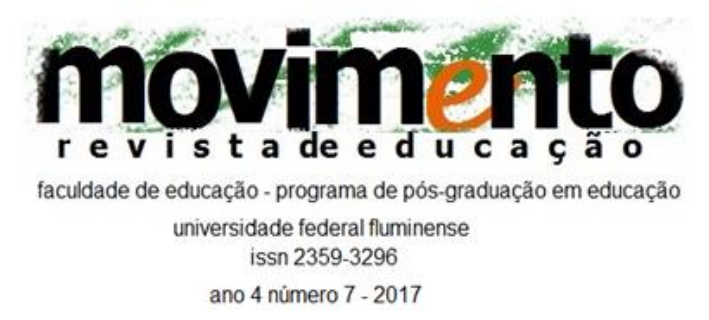

constitui-se como uma forma singular de mediação social, por ser intencional, afetando, constituindo e transformando o funcionamento mental dos sujeitos e provocando uma mudança em todo o desenvolvimento cultural das crianças.

Se o processo de aquisição da escrita deve acontecer enquanto necessidade social, ou seja, uma forma do sujeito se apropriar da cultura, é necessário que a criança passe a se colocar na escola, interaja, tenha o que dizer e amplie o seu discurso social. $\mathrm{O}$ foco de trabalho do professor, no lugar de ensinar palavras soltas e sem significado, passa a ser o texto. Nessa perspectiva, ao falar da produção de textos, não é possível associar as propostas de redação aos velhos moldes, pois um texto é algo bem mais amplo, tanto do ponto de vista linguístico quanto do discursivo.

Assim, o texto, enquanto enunciado e unidade da comunicação discursiva (orais e escritos), constitui-se como um todo de sentido que não se limita à dimensão linguística, mas concebe a situação social como elemento constitutivo. Caracteriza-se como um querer-dizer feito pelo autor prevendo um destinatário. Dessa forma, em relação dialógica é sempre um querer dizer para um outro. Nesses termos, a primeira produção textual da criança poderá ser seu nome. Esse texto é carregado de significação e pode ser explorado tanto nos aspectos notacionais da língua (quais letras usar, os sons dessas letras nessa e em outras palavras, como realizar o traçado dessas letras, etc.), quanto nos discursivos (a origem do nome da criança, seu significado social, qual o nome das demais crianças e da professora, a escolha histórica e política dos nomes desses sujeitos, etc.).

No processo inicial de alfabetização, ou seja, nos primeiros contatos com a escrita, é necessário deixar que a criança escreva seus primeiros textos, mesmo sem o domínio da ortografia, pois 


\section{movimento \\ faculdade de educação - programa de pós-graduação em educação universidade federal fluminense issn 2359-3296 \\ ano 4 nümero 7 - 2017}

[...] em resumo, as crianças, ainda em fase de alfabetização, demonstram capacidade para produzir textos espontâneos. Nesse processo, ao enfrentar 0 desafio de novas palavras, constroem hipóteses sobre a ortografia, sem perder a facilidade de expressão que já adquiriram oralmente. (CAGLIARI, 2009, p. 107).

Coadunamos com o pensamento desse autor e destacamos a necessidade de fazer, ao mesmo tempo, um trabalho enfocando as habilidades orais e escritas, nas quais o professor vai pontuando as intervenções em sua fala, ora coletivamente, ora de forma individual, dos elementos que enriquecem os textos, explorando as especificidades de seus usos e funções sociais. Inicialmente, esse processo se dá de forma oral e, posteriormente, vai se constituindo como escrito, a partir da apropriação do sistema de escrita alfabética. Esses elementos se referem à forma de estruturar o discurso, à coesão, à argumentação, à organização das ideias, à escolha das palavras, aos objetivos e ao foco no destinatário do texto.

Essas habilidades são apropriadas pela criança de acordo com as intervenções pedagógicas e as interações proporcionadas entre os diferentes sujeitos do processo educativo. Quanto às práticas de leitura em sala de aula, o trabalho com o texto não pode ser utilizado apenas para a leitura em voz alta ou se constituir como pretexto para o ensino da gramática. A leitura precisa abranger não apenas a superficialidade do texto, mas, também, um trabalho que proporcione à criança o desejo de querer saber mais, tanto da forma quanto do conteúdo do texto. É preciso que haja a exploração das configurações textuais, da compreensão da polissemia e da intertextualidade contida no objeto de estudo. (GERALDI, 2003).

Quanto ao aspecto político da alfabetização, é necessária a proposição de práticas alfabetizadoras que reflitam sobre os aspectos notacionais da língua (seu funcionamento, estrutura e função) e, ao mesmo tempo, possibilitem à criança ampliar, de forma crítica, as suas percepções de mundo e sua 


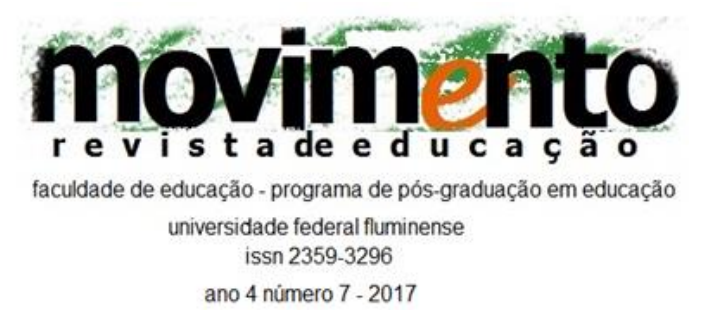

consciência. Dessa forma, de uma consciência ingênua para a crítica, tem-se presente os mesmos elementos que se constituem como princípios para a formação humana apresentados por Freire no trabalho com adultos.

$\mathrm{Na}$ etapa da alfabetização, o que se pretende não é ainda uma compreensão profunda da realidade que se está analisando, mas desenvolver aquela posição curiosa... estimular a capacidade crítica dos alfabetizandos enquanto sujeitos do conhecimento, desafiados pelo objeto a ser conhecido. É exatamente a experiência sistemática desta relação que é importante. A relação do sujeito que procura conhecer com o objeto a ser conhecido. Relação que inexiste toda vez que, na prática, o alfabetizando é tomado como paciente do processo, puro recipiente da palavra do alfabetizador. Neste caso, então, não diz a sua palavra. (FREIRE, 1989, p. 26).

Nesse sentido, Freire (1989, p. 07) aponta a necessidade de articular o texto e o contexto nas práticas de alfabetização, ou seja, "aprender a ler o mundo, compreender o seu contexto, não numa manipulação mecânica de palavras, mas numa relação dinâmica que vincula linguagem e realidade".

É compreendendo a necessidade de articular a leitura da palavramundo às práticas significativas de leitura e de escrita que ressaltamos a importância de um planejamento pedagógico que não esteja focado apenas no treinamento de habilidades e de competências linguísticas, mas também considere os conhecimentos prévios da criança para ampliá-los com o conhecimento científico, sendo capaz de ressignificar as experiências cotidianas e de desenvolver a conscientização.

Dessa forma, o planejamento de atividades em alfabetização deve considerar: os sujeitos, as suas experiências e os seus interesses, os conhecimentos científicos que se articulam a essas experiências e que podem ampliá-las e a compreensão de que o professor precisa ensinar e que todos podem aprender. Esse movimento formativo deve ser organizado prevendo que a interação entre os sujeitos da escola pode potencializar a aprendizagem. 


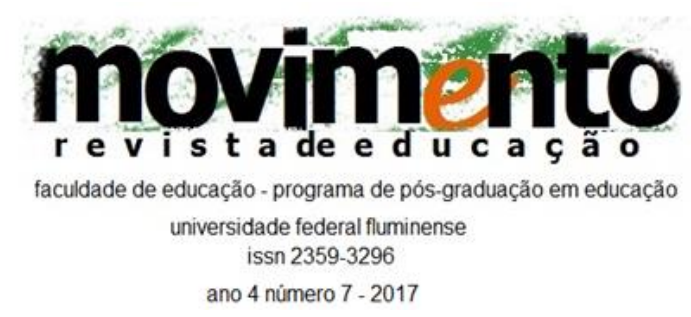

Nesse espaço alfabetizador, a leitura e a escrita são atividades diárias, contextualizadas, e devem ser articuladas ao desenvolvimento da oralidade da criança. É preciso ofertar diferentes oportunidades de produção, sempre permeadas "por um sentido, por um desejo, e implica ou pressupõe, sempre, um interlocutor". (SMOLKA, 2008, p. 69).

Geraldi (2003), quanto à formação docente, compreende que a exigência da utilização dos textos em sala de aula requer do docente um aporte teórico reflexivo para a constituição de um novo professor. Nesse sentido, é preciso que as práticas pedagógicas estejam voltadas ao ensino da língua escrita, a partir do funcionamento desta, e do seu uso real, e não por meio de frases soltas e sem sentido. Dessa forma, é necessário investir em uma proposta de formação continuada que não enfoque o trabalho com métodos, mas instigue o professor a interpretar o que é a linguagem e como ela funciona, refletindo acerca dos seus usos e das suas possibilidades de se formar um sujeito leitor/escritor que interaja na e pela linguagem.

Dessa forma, compreendendo o papel fundamental do professor para a constituição do sujeito leitor, é necessário ter um professor alfabetizador que se forme nessa perspectiva, que reconheça, nos primeiros textos das crianças espaços constituídos de enunciação, e que consiga, no espaço da escola, criar um ambiente alfabetizador, percebendo o que ainda precisa ser proporcionado às crianças a partir do movimento de uma prática que se faz e refaz, da práxis envolvendo $o$ ato de planejar, de avaliar e de propor.

Quanto à análise dos textos dos educandos, para além dos aspectos notacionais da língua, é necessário se ater ao que ele pode nos revela. Quais os conhecimentos precisam ser ressignificados/ampliados, o que a criança sabe sobre a escrita (propriedades do sistema de escrita alfabética), quais os 


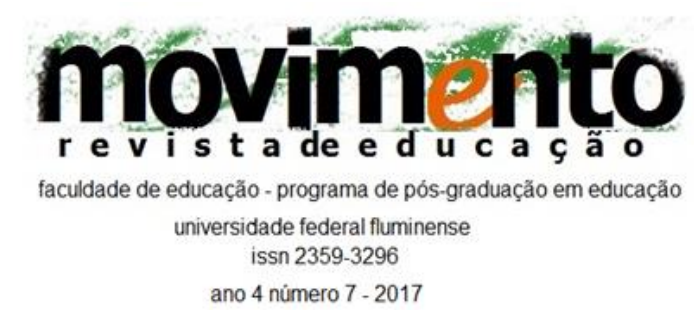

conhecimentos prévios revelados em seu texto, quais as "marcas" de sua fala social.

Quando consideramos os primeiros textos das crianças como espaço de enunciação, retomamos dialeticamente as mediações realizadas para pensar e repensar o que ainda precisa ser proporcionado. Nesse movimento de planejar, de avaliar e de propor, Paulo Freire retoma a necessidade de se pensar a prática pedagógica enquanto práxis:

É por isso que penso e re-penso o processo de alfabetização como quem está sempre diante de uma novidade, mesmo que, nem toda vez tenha novidades sobre o que falar. Mas, ao pensar e ao re-pensar a alfabetização, penso ou repenso a prática em que me envolvo. Não penso ou re-penso o puro conceito, desligado do concreto, para, em seguida, descrevê-lo. (FREIRE, 1989, p. 22).

Para Freire (2006, p. 80), a formação continuada dos professores é um elemento fundante, necessário e constante, pois a dinâmica do trabalho pedagógico se dá no movimento de uma prática que se faz e se refaz. A lógica do trabalho pautase na ação-reflexão-ação, destacando o compromisso do educador em um fazer pedagógico sério e competente que responda aos anseios da escola que se busca construir.

Para isso, o autor destaca algumas possibilidades de formação continuada: em pequenos grupos na escola e também em grupos ampliados, envolvendo sujeitos de diferentes escolas. O contato entre professores de diferentes escolas pode suscitar o debate sobre proposições para a alfabetização. Já o trabalho de parceria entre os professores alfabetizadores da mesma escola pode contribuir para a aprendizagem dos educandos ao possibilitar diferentes movimentos formativos envolvendo as crianças.

Quanto à relação conteúdo e forma na alfabetização, se o conteúdo elencado a partir dos temas geradores busca dar sentido às práticas de alfabetização, a 


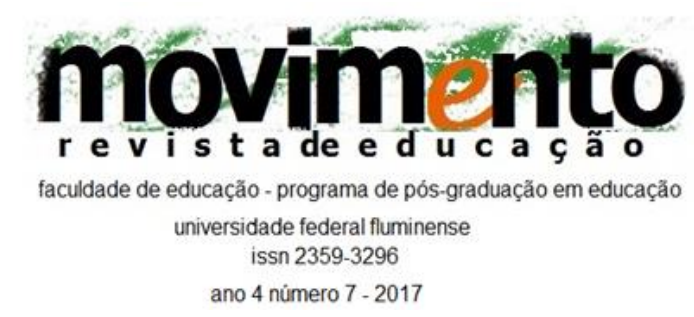

forma de trabalhar com ele se transforma, porque ocorre uma alteração implícita das concepções de linguagem e de sujeito envolvidas. Essa mudança metodológica só ocorre, porque se tem como foco a proposição de atividades que reconheçam a necessidade da criança de conhecer o mundo de se apropriar da cultura.

\section{Considerações finais}

O sentido da formação para Freire (2006) pontua claramente a escola que queremos como espaço público e popular, de direito de todos, no qual se destaque a apreensão crítica do conhecimento por meio de relações dialógicas. Uma escola que estimula o aluno a pensar, a perguntar, a criar, a criticar e ensina a duvidar das certezas postas. Propõe-se construir um conhecimento coletivo, articulando os saberes populares ao saber científico, de forma crítica, mediados pelas experiências no mundo.

Paulo Freire compreende a necessária participação social, não sobre o aspecto meramente formal, mas como meio que conjugue conhecimento utopia e ação voltadas para a mudança social de uma base opressiva para possibilidades emancipatórias. Nesse sentido, o autor desenvolve e articula a práxis política com temas como a ética, a autonomia, a libertação, a utopia, o diálogo, a construção do conhecimento e a conscientização. Nesse diálogo, ele diz a sua palavra com outros homens, os oprimidos, e também com a realidade de opressão, propondo mudá-la.

Para a construção de novas possibilidades de relações sociais livres da lógica da opressão entre opressores e oprimidos, Paulo Freire nos propõe pensar práticas educativas pautadas no diálogo entre educandos e educadores. Uma educação pelo diálogo pressupõe a escuta atenta ao outro e sempre um falar 


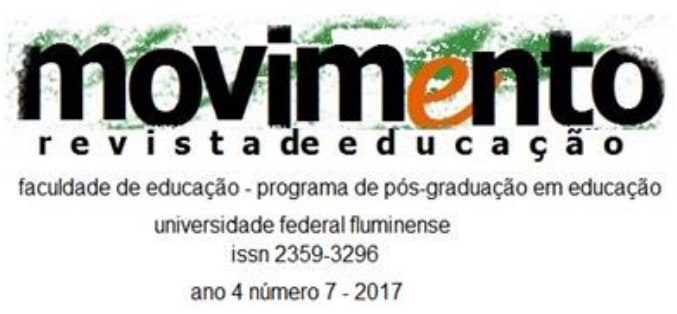

com e nunca um falar para o outro. Implica, assim, uma atuação pedagógica pensada com todos os sujeitos envolvidos e não pré-moldada para eles.

Nesse sentido, a alfabetização tem a proposição de ser emancipadora ao propor a leitura da palavramundo, pois, além das palavras, é necessário ler e compreender a realidade para transformá-la. Nesse movimento, a significação do ato de ler ganha sentido para o alfabetizando, já que parte da consideração da realidade desse sujeito.

Esses sujeitos, que tendo consciência de sua história e das relações de poder determinadas historicamente, desenvolvem uma visão politizada, ou seja, uma compreensão rigorosa dos fatos, apreendendo suas determinações e contradições históricas. Para gerar esse nível de esclarecimento, justifica-se uma alfabetização que transcenda a mera apreensão do código escrito e se reinvente enquanto ato filosófico e político para diminuir a distância entre a práxis e o discurso.

Com isso, é necessário que as práticas alfabetizadoras enxerguem além dos muros da escola, que direcionem o olhar para os sujeitos e que comecem a considerar os educandos que recebem diariamente. $O$ sentido da formação humana para Freire amplia o nosso olhar ao nos incitar a uma relação dialógica com as crianças que alfabetizamos e ao assumirmos a responsabilidade pela formação política e ética com e por elas.

Nessa lógica, é importante que o movimento formativo no espaço escolar comece a partir da escuta das crianças que recebemos na escola para, somente então, organizar as suas proposições, o seu planejamento, as suas intervenções e a sua avaliação do trabalho pedagógico. Assim, deve-se considerar quem são essas crianças com as quais se trabalha, como elas aprendem, como se pode ensiná-las, como construir um ambiente alfabetizador com elas e como articular 


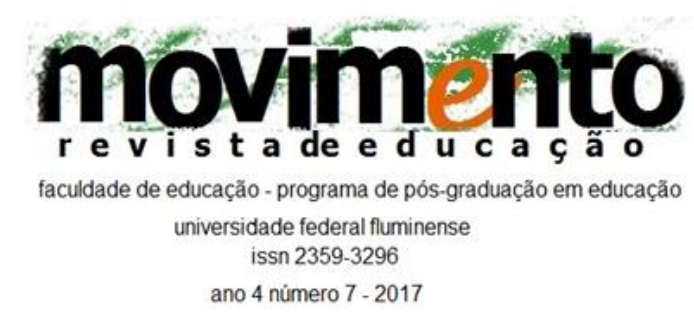

um currículo que garanta, desde o primeiro ano da educação fundamental, o acesso às diferentes áreas do conhecimento.

\section{Referências}

BEISIGEL, C. et. al. Paulo Freire: inspirações. São Paulo: Paulus: ATTA Mídia e Educação, 2008.

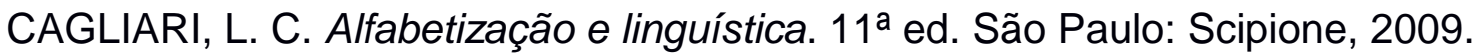

FREIRE, P. Pedagogia do oprimido. 17ª ed. Rio de Janeiro: Paz e Terra, 1987. Pedagogia da esperança: um reencontro com a pedagogia do oprimido. Rio de Janeiro: Paz e Terra, 1997. Moraes, 1979.

Conscientização: teoria e prática da libertação. São Paulo: Cortez \& . A importância do ato de ler: em três artigos que se completam. São Paulo: Cortez, 1989.

Pedagogia da autonomia: saberes necessários à prática educativa. Rio de Janeiro: Paz e Terra,1996.

. A educação na cidade. $7^{\mathrm{a}}$ ed. São Paulo: Cortez, 2006.

GADOTTI, M. Paulo Freire: uma bibliografia. São Paulo: Cortez/Instituto Paulo Freire; Brasília, DF, UNESCO, 1996.

GERALDI, J. W. Portos de Passagem. 4ํㅡㄹ ed. São Paulo: Martins Fontes, 2003.

KRAMER, S. Escrita, experiência e formação. In: YUNES, E; OSWALD, M. L. A experiência da leitura. São Paulo: Loyola, 2003.

SMOLKA, A. L. B. A criança na fase inicial da escrita: a alfabetização como processo discursivo. São Paulo: Cortez; Campinas, 2008. 


\section{movimento \\ r e v i s t a de e d u c a ç ã o \\ faculdade de educação - programa de pós-graduação em educação \\ universidade federal fluminense \\ issn 2359-3296 \\ ano 4 número 7 - 2017}

SHOR, I.; FREIRE, P. Medo e Ousadia - O Cotidiano do Professor. Rio de Janeiro: Paz e Terra, 1986.

Recebido em: 28.08.2017

Aceito em: 21.10.2017 